\title{
Inovasi Multi-Channel Learning Dalam E-Business Management pada Pendidikan Tinggi
}

\author{
Nany Pancawardany ${ }^{*}$, Sigit Sigalayan ${ }^{2}$ \\ ${ }^{1}$ Program Studi Akuntansi, Fakultas Ekonomi dan Bisnis, Universitas Mulia \\ ${ }^{2}$ Program Studi Informatika, Fakultas Ilmu Komputer, Universitas Mulia \\ "nany@universitasmulia.ac.id
}

\begin{abstract}
In the industrial era 4.0, technology and the internet have become an important role in the development of life in the world. In the context of information technology and communication technology are two inseparable concepts. The advancement of information technology, especially computer-based communication technology, is very rapid. This communication technology offers an alternative way to carry out learning activities. Computerbased learning requires students to be actively involved and participative in the learning process. The word teaching is used to indicate an educational effort that is carried out deliberately with predetermined goals, before the process is carried out, and whose implementation is controlled. With the development of information and communication technology today, learning must be integrated with the web. Multi-Channel Learning is a model that can be applied to education, combining several learning models such as face-to-face, virtual, and online. This goal is so that students and lecturers can carry out learning anywhere and anytime.
\end{abstract}

Keywords: elearning, inovasi, internet, management, multi channel learning

\begin{abstract}
Abstrak
Di era industry 4.0 teknologi dan internet menjadi salah satu peran penting dalam perkembangan kehidupan di dunia. Dalam konteks teknologi informasi dan teknologi komunikasi merupakan dua konsep yang tidak dapat dipisahkan.. Kemajuan teknologi informasi khususnya teknologi komunikasi berbasis komputer sangat pesat. Teknologi komunikasi tersebut menawarkan cara alternatif untuk melaksanakan kegiatan pembelajaran. Pembelajaran berbasis komputer menuntut peserta didik terlibat aktif dan partisipatif dalam proses pembelajaran. Kata pembelajaran digunakan untuk menunjukkan usaha pendidikan yang dilaksanakan secara sengaja dengan tujuan yang telah ditetapkan terlebih dahulu, sebelum proses dilaksanakan, serta yang pelaksanaannya terkendali. Dengan perkembangan teknologi informasi dan komunikasi saat ini, pembelajaran harus terintegrasi dengan web. Multi Channel Learning merupakan salah satu model yang dapat diterapkan untuk pembelajaran, memadukan beberapa model pembelajaran seperti tatap muka, virtual, dan online. Tujuan tersebut adalah agar peserta didik dan dosen dapat melangsungkan pembelajaran dimanapun dan kapanpun.
\end{abstract}

Kata kunci: elearning, inovasi, internet, management, multi channel learning

\section{Pendahuluan}

\subsection{Pengajaran}

Dalam proses mengajar perlu strategi, dan begitu pula pada setiap pengajaran membutuhkan strategi mengajar. Pengajar pada perguruan tinggi yaitu dosen perlu menerapkan strategi tersebut agar capaian materi perkuliahan dapat terlaksana dengan baik, khususnya pada perkuliahan $e$-business management. Model yang berhubungan dengan strategi belajar pada mahasiswa telah telah banyak dibahas dan diterapkan. Namun, model yang berhubungan dengan strategi mengajar bagi dosen belum diteliti secara mendalam dan menyeluruh. Strategi mengajar yang efektif adalah penting, khususnya bagi dosen yang mengajar pada kelas dengan sistem multi channel learning. Multi Channel Learning (MCL) adalah sistem pembelajaran yang menggabungkan beberapa channel pembelajaran yaitu;

1) Face to Face; 
Face to face (F2F) atau kuliah di kelas dengan model tatap muka, dosen dan mahasiswa dalam hal ini bertatap muka dan secara langsung berkomunikasi mengenai mata kuliah yang akan dibahas.

2) Self-study;

Self study atau belajar mandiri, yaitu belajar tanpa diperintah oleh dosen, pada channel pembelajaran model ini mahasiswa ataupun mahasiswi diwajibkan belajar sendiri tanpa bimbingan dosen pengajar dalam pengertian mencari sumber-sumber informasi lain yang dapat dijadikan pembelajaran, sebab dosen hanya menjelaskan sebagian kecil dari materi pembelajaran pada saat didalam kelas.

3) E-learning.

chanel pembelajaran model e-learning ini lebih difokuskan pada diskusi online antar dosen dan mahasiswa didalam forum, jadi dalam hal ini dosen memberikan beberapa materi dan kasus atau pertanyaan yang harus dijawab oleh mahasiswa.

Dari beberapa model MCL diatas maka penelitian ini akan focus pada inovasi MCL yang akan dikembangkan pada mata kuliah $e$ business management di perguruan tinggi yaitu pada Universitas Mulia.

\subsection{Multi Channel Learning}

Peserta didik tak lagi mengandalkan ilmu pengetahuan yang disajikan oleh pengajar atau dosen. Saat ini pendidikan tinggi telah menerapkan sistem pembelajaran global (global learning system) untuk memperkuat basis komunikasi antardosen dan peserta didik ke berbagai wilayah, tanpa batas ruang dan waktu. Didukung dengan perangkat teknologi yang modern menjadikan pembelajaran sangat mudah dilakukan.

Perkembangan teknologi yang telah digunakan pada pendidikan tinggi memungkinkan terciptanya suatu jaringan pembelajaran yang efektif, baik antara peserta didik satu dengan yang lainnya bersama dosen dapat terhubung melalaui satu jaringan yang telah disediakan. Secara tidak langsung seiring dengan perkembangan teknologi ini peserta didik sedikit dipaksakan untuk dapat memanfaatkan fasilitas-fasilitas yang telah tersedia disekitarnya, seperti internet, smartphone dan komputer.

Melalui perangkat hardware dan software yang dimiliki oleh peserta didik dan dosen maka MCL dapat dengan mudah diterapkan, yaitu dengan menggabungkan beberapa model dalam pembelajaran ebusiness management.

\subsection{Rumusan Masalah}

Berdasarkan latar belakang masalah, maka rumusan penelitian dapat dirumuskan sebagai berikut:

1. Bagaimana mengembangkan inovasi mengajar menggunakan multi channel learning?

2. Bagaimana strategi mengajar untuk mengetahui titik temu antara dosen dan mahasiswa tanpa berbatas ruang dan waktu?

\subsection{Tujuan Penelitian}

Adapun Tujuan Penelitian tersebut adalah sebagai berikut:

1. Untuk menyelidiki strategi belajar mengajar antara peserta didik dan dosen pada perguruan tinggi

2. Untuk membangun sebuah inovasi multi channel learning dalam membantu proses belajar mengajar pada matakulia $e$ business management.

\subsection{Urgensi Penelitian}

Urgensi penelitian dalam menerapkan MCL, adalah sebagai berikut:

1. Sebagai salah satu solusi pembelajaran untuk membantu peserta didik dan dosen dalam menyampaikan materi dan tugas yang dapat diakses sewaktu-waktu

2. Sebagai pilihan model pembelajaran yang dapat diterapkan dimana saja, dapat bertatap muka, dan e-learning ataupun hybrid yaitu menggabungkan atara keduanya.

3. Untuk mengembangkan inovasi pada penggunaan teknologi informasi yang dapat hemat dan efisien khususnya pada penggunaan inovasi MCL.

4. Sebagai acuan referensi bagi penulis maupun peneliti lainnya dalam mendukung membangun inovasi MCL berikutnya.

\subsection{Spesifikasi Sistem}

Sistem MCL akan dibangun berbasis web dan dapat diakses secara online, menggunakan pemrograman php dan mysql, dan beberapa spesifikasi standar komputer baik hardware dan software serta akses internet yang dibutuhkan untuk implementasi 
sistem tersebut. MCL dapat juga diterapkan secara online tanpa terhubung internet, yaitu dengan menggunakan jaringan local yang telah ada pada institusi Pendidikan tinggi.

\subsection{Kajian Pustaka}

Berdasarkan kajian multichannel learning, yaitu model pembelajaran dapat digabungkan menjadi beberapa channel pembelajaran yaitu; Face to face, self study dan e-learning.

(1) Face to face (F2)

Pembelajaran dengan menggunakan tatap muka antara dosen dan peserta didik.

\section{(2) Self Study}

Model pembelajaran mandiri, yang dapat bersumber dari dosen dan dari sumber lainnya untuk memudahkan pemahaman dan penguasaan materi dan tugas.

\section{(3) Elearning}

Didunia telah banyak institusi pendidikan tinggi yang menggunakan internet serta teknologi digital untuk dikembangkan dalam kegiatan mengajar dan belajar [1]. Untuk menggambarkan berbagai sistem pembelajaran ini sejumlah istilah digunakan seperti computer mediated learning, web based training dan yang paling sering adalah e-learning [2]. Elearning adalah singkatan dari elektronic learning, dimana proses belajar mengajar yang menggunakan media elektronik secara khusus internet sebagai sistem pembelajarannya [3].

E-learning adalah payung istilah yang meliputi berbagai konsep dan teknologi yang berkaitan dengan pembelajaran, seperti jarak, digital, elektronik, online, berbasis web dan pembelajaran mobile. Elearning punya banyak keuntungan, ini mengurangi waktu tempuh, fleksibel dan fleksibel dapat diakses, bisa hemat biaya dan bisa memungkinkan peserta didik untuk belajar dengan kecepatan mereka sendiri dan dari tempat yang mereka pilih. Selanjutnya, e-learning berpotensi menyediakan konten disesuaikan dan metode instruksional berbasis pada kebutuhan individu peserta didik dan dapat hadir berbagai komponen multimedia seperti teks, audio, diam dan gerak visual untuk mendukung perolehan pengetahuan dan keterampilan. Bahkan jika tidak ada bukti kuat untuk dibuktikan bahwa $e$-learning lebih unggul dari pembelajaran tradisional, hasilnya dari tinjauan sistematis mendukung bahwa ini adalah sebuah efisiensi cara alternatif untuk belajar. Apalagi berdampak positif pada pengetahuan perawat, keterampilan, tingkat self-efficacy dan kepuasan [4].

a) Infrastruktur e-learning

Untuk mendukung e-learning diperlukan

(a) Penggunaan energi terbarukan, seperti generator listrik (b) memperkuat bandwidth internet (c) penggunaan intranet (d) ekstensi laboratorium komputer dan peralatan (e) Penciptaan pusat regional meningkat akses pendidikan [5]

b) Penggunaan $e$-learning

Untuk meningkatkan bentuk pengajaran tradisional dan administrasi di universitas $e$ learningtelah digunakan dengan sangat efektif didalam pengajaran di universitas [1]. LMS (Learning Manajemen Sistem) adalah perangkat lunak untuk membuat materi perkuliahan online (berbasis web) yang pada era sekarang diimplementasikan dengan menggunakan LMS Moodle. Berbagai aktivitas dapat didukung oleh LMS diantaranya adalah pelacakan/tracking \& monitoring, kolaborasi, administrasi, peyampaian materi pembelajaran, penilaian (tugas, quiz), serta interaksi atau komunikasi. Yang termasuk asynchronous adalah LMS, Email, Blog, Discusion Board, Collaborate [6].

\section{c) Standar e-learning}

Standar e-learning dimana elearning dapat mengidentifikasi manfaat dari peningkatan standarisasi [7] :

1) Pengguna dapat bergerak dengan mudah antara aplikasi pembelajaran karena antarmuka standar;

2) Format konten yang umum;

3) Pengurangan biaya pengembangan untuk vendor alat;

4) Integrasi komponen dan penggunaan kembali oleh perancang aplikasi dan platform.

d) Teori pendukung pelaksanaan elearning

Tingkat kesiapan, aspek kontrol siswa merupakan variabel yang penting dalam $e$ learning. Karakteristik yang cukup nyaman maka proses belajar siswa dapat berhasil. Kontrol atas kegiatan belajar mereka sendiri yang membuat keputusan, kedalaman konten, 
lingkup, jenis media yang diakses dan waktu yang digunakan untuk belajar [8]. Karakteristik pelajar yang memiliki kesiapan pelaksanaan Online-learning meliputi kemanjuran diri, tempat kontrol, dan percaya diri dalam penggunaan teknologi [9]. Berkaitan dengan penelitian ini maka peneliti meninjau dari beberapa teori belajar yang relevan dan mendukung pelaksanaan $e$ learning.

1) Teori Konstruktivisme

Teori ini beranggapan bahwa pengetahuan adalah hasil konstruksi manusia. Manusia mengkonstruksi pengetahuannnya melalui interaksi dengan objek, fenomena, pengalaman, dan lingkungan mereka.

2) Teori kemandirian dan otonomi

Teori ini menganggap kemandirian peserta didik sebagai hal yang penting dalam pendidikan jarak jauh. Menurut American theory of independent study (belajar mandiri) [10], suatu sistem pendidikan jarak jauh sebaiknya memenuhi hal-hal berikut : mampu beroprasi dimanapun peserta didik berada, menempatkan tanggung jawab belajar pada peserta didik, memberikan lebih banyak waktu mengerjakan tugas-tugas pendidikan, menawarkan pilihan lebih banyak dalam bentuk kursus, format, dan metodologi, menggunakan semua media dan metode pembelajaran yang terbukti efektif, menggabungkan media dan metode sehingga setiap mata pelajaran diajarkan secara tepat, menyesuaikan rancangan dan pengembangan kegiatan dengan program media tersebut, menjaga dan meningkatkan kesempatan beradaptasi bagi perbedaan individu, mengevaluasi hasil belajar, tidak memperhitungkan hambatan dalam hal tempat, metode atau urutan belajar peserta didik, peserta didik bebas memulai, mengakhiri, dan belajar dengan caranya sendiri.

3) Teori interaksi dan komunikasi

Holmber dalam teorinya guide didactic conversation [11] memandang materi belajar jarak jauh adalah gaya komunikasi yang tidak berbatasan sebagai instrument percakapan, seperti interaksi antar peserta didik dan tutor.

Faktor-faktor yang mempengaruhi penggunaan e-learning [12].
1) faktor-faktor yang mempengaruhi niat penggunaan oleh mahasiswa [12]., yaitu :

a) Persepsi kegunaan (PU) didefinisikan suatu tingkatan dimana seseorang percaya bahwa dengan menggunakan suatu sistem tertentu akan meningkatkan performa kerja mereka.

b) Persepsi kemudahan penggunaan (PE) didefinisikan sebagai suatu tingkatan dimana seseorang percaya bahwa dengan menggunakan suatu sistem tertentu akan bebas dari suatu upaya

c) Keyakinan diri (SE) di definisikan sebagai penilaian seseorang terhadap kemampuan mereka sendiri dalam mengatur dan melakukan aksi yang dibutuhkan untuk mencapai hasil yang diinginkan.

d) Norma subjektif ( $\mathrm{SN}$ ) didefinisikan sebagai suatu persepsi tekanan sosial untuk melakukan atau tidak melakukan suatu.

2) Menggunakan UTAUT (Unified Theory of Acceptance and Use of Technology Model) untuk faktor yang mempengaruhi penggunaan $e$-learning, yaitu :

a) ekspektasi usaha

b) ekspektasi kinerja

c) pengaruh sosial

3) Standar mutu e-learning

Standar mutu penyelenggaraan mata kuliah berbasi e-learning [13].

Tabel 1. Standar Mutu Penyelenggaraan Mata Kuliah Berbasi E-learning

\begin{tabular}{|l|l|l|}
\hline Komponen & Standar Mutu & Indikator \\
\hline Perencanaan & - Kuliah yang & - Dokumen \\
& dilaksanakan & rancangan \\
& harus mendapat & perkuliahan \\
& persetujuan/ & yang telah \\
& disahkan & memperoleh \\
& Fakultas/ & persetujuan \\
& Universitas & Fakultas/Univer \\
& - Dosen dan & sitas \\
& mahasiswa harus & - Tersedianya \\
& memiliki akses & akses terhadap \\
& terhadap intranet & intranet atau \\
& dan internet & internet dengan \\
& & mudah, biaya \\
& - Dosen harus & terjangkau dan \\
& memiliki akses & kecepatan \\
& terhadap fasilitas & memadai \\
& pengembangan & - Tersedianya \\
& pengajaran & akses dan \\
& berbasis & fasilitas yang \\
& elearning & memadai untuk \\
& Tersedia buku & pengembangan \\
& rancangan & \\
\hline
\end{tabular}




\begin{tabular}{|c|c|c|}
\hline & $\begin{array}{l}\text { pengajaran } \\
\text { berbasis } e \text { - } \\
\text { learning Tersedia } \\
\text { akses terhadap } \\
\text { fasilitas pelatihan } \\
\text { penyelenggaraan } \\
\text { elearning }\end{array}$ & $\begin{array}{l}\text { pembelajaran } e \text { - } \\
\text { learning } \\
\text { - Tersedianya } \\
\text { buku rancangan } \\
\text { pengajaran } \\
\text { sebagai bagian } \\
\text { dari pedoman } \\
\text { akademik } \\
\text { - Tersedia akses } \\
\text { dan fasilitas } \\
\text { pendukung } \\
\text { terhadap } \\
\text { fasilitas } \\
\text { pelatihan } \\
\text { penyelenggaraa } \\
\text { n elearning }\end{array}$ \\
\hline $\begin{array}{l}\text { Perancangan } \\
\text { dan } \\
\text { Pembuatan } \\
\text { Materi }\end{array}$ & $\begin{array}{l}\text { Materi harus } \\
\text { sesuai dengan } \\
\text { kurikulum dan } \\
\text { media elektronik } \\
\text { yang tersedia } \\
\text { - Materi disiapkan } \\
\text { oleh dosen di } \\
\text { bidang ilmu } \\
\text { terkait } \\
\text { - Perancangan dan } \\
\text { pembuatan materi } \\
\text { harus sesuai } \\
\text { dengan } \\
\text { karakteristik } \\
\text { pembelajaran } e- \\
\text { learning } \\
\text { Materi harus } \\
\text { tersedia dan dapat } \\
\text { diakses } \\
\text { mahasiswa tanpa } \\
\text { terikat tempat dan } \\
\text { waktu } \\
\text { Menjalankan } \\
\text { penyelenggaraan } \\
\text { elearning dengan } \\
\text { kode etik, } \\
\text { peraturan dan } \\
\text { perundangan } \\
\text { yang berlaku }\end{array}$ & $\begin{array}{l}\text { - Kesesuaian } \\
\text { materi dan } \\
\text { kurikulum } \\
\text { - Dokumen } \\
\text { materi telah } \\
\text { memperoleh } \\
\text { persetujuan dari } \\
\text { dosen senior di } \\
\text { bidang ilmu } \\
\text { terkait } \\
\text { Kesesuaian } \\
\text { antara } \\
\text { perancangan } \\
\text { dan pembuatan } \\
\text { materi } \\
\text { karakteristik } \\
\text { pembelajaran } e \text { - } \\
\text { learning } \\
\text { - Ketersediaan } \\
\text { materi yang } \\
\text { dapat diakses } \\
\text { oleh mahasiswa } \\
\text { tanpa terikat } \\
\text { waktu dan } \\
\text { tempat } \\
\text { - Kesesuaian dari } \\
\text { proses } \\
\text { penyelenggaraa } \\
\text { n elearning } \\
\text { dengan kode } \\
\text { etik, peraturan } \\
\text { dan } \\
\text { perundangan } \\
\text { yang berlakua }\end{array}$ \\
\hline Penyampaian & $\begin{array}{l}\text { Minimum materi } \\
\text { tersedia dalam } \\
\text { presentasi } \\
\text { elektronik } \\
\text { - Penyampaian } \\
\text { materi harus } \\
\text { sesuai dengan } \\
\text { program mapping } \\
\text { yang telah } \\
\text { ditentukan } \\
\text { - Materi harus } \\
\text { menarik dari segi } \\
\text { isi dan layout, } \\
\text { terkini } \\
\text { - Harus tersedia } \\
\text { fasilitas tatap } \\
\text { muka } \\
\text { - Tersedia fasilitas } \\
\text { yang }\end{array}$ & $\begin{array}{l}\text { - Keragaman dan } \\
\text { macam bentuk } \\
\text { presentasi } \\
\text { elektronik yang } \\
\text { digunakan } \\
\text { dalam elearning } \\
\text { - Kesesuaian } \\
\text { antara cara atau } \\
\text { metode } \\
\text { penyampaian } \\
\text { materi dengan } \\
\text { program } \\
\text { mapping yang } \\
\text { telah ditentukan } \\
\text { - Materi yang } \\
\text { tersedia dapat } \\
\text { dan mudah } \\
\text { diperbarui serta } \\
\text { up to date, }\end{array}$ \\
\hline
\end{tabular}

\begin{tabular}{|c|c|c|}
\hline & $\begin{array}{l}\text { memudahkan } \\
\text { mahasiswa } \\
\text { melakukan akses } \\
\text { materi. }\end{array}$ & $\begin{array}{l}\text { menarik dan } \\
\text { mudah } \\
\text { dipahami. } \\
\text { - Tingkat } \\
\text { ketersediaan } \\
\text { fasilitas tatap } \\
\text { muka } \\
\text { - Akses } \\
\text { mahasiswa }\end{array}$ \\
\hline Interaksi & $\begin{array}{l}\text { - Pembelajaran } \\
\text { dirancang } \\
\text { terjadinya } \\
\text { interaksi antar } \\
\text { mahasiswa, } \\
\text { dosen, dan materi } \\
\text { - Interaksi dapat } \\
\text { dilakukan baik } \\
\text { secara } \\
\text { synchronous } \\
\text { maupun } \\
\text { asynchronus }\end{array}$ & $\begin{array}{l}\text { - Interaksi antar } \\
\text { mahasiswa, } \\
\text { dosen, dan } \\
\text { materi secara } \\
\text { online, diskusi, } \\
\text { tugas. } \\
\text { - Interaksi dapat } \\
\text { dilakukan baik } \\
\text { secara } \\
\text { synchronous } \\
\text { maupun } \\
\text { asynchronus }\end{array}$ \\
\hline Evaluasi & $\begin{array}{l}\text { Ada evaluasi } \\
\text { dosen, } \\
\text { mahasiswa, } \\
\text { proses (materi, } \\
\text { tatacara, } \\
\text { dukungan } \\
\text { fasilitas selama } \\
\text { penyelenggaraan } \\
\text { e-learning) } \\
\text { - Penilaian tercatat } \\
\text { dalam system } \\
\text { informasi } \\
\text { akademik }\end{array}$ & $\begin{array}{l}\text { - Dilakukan } \\
\text { evaluasi dosen, } \\
\text { mahasiswa, } \\
\text { proses (materi, } \\
\text { tatacara, } \\
\text { dukungan } \\
\text { fasilitas selama } \\
\text { penyelenggaraa } \\
\text { n } e \text {-learning) } \\
\text { - Data tercatat } \\
\text { dalam system } \\
\text { informasi } \\
\text { akademik }\end{array}$ \\
\hline
\end{tabular}

\section{Metoda Penelitian}

Metode yang akan digunakan adalah metode kualitatif dan kuantitatif.

\subsection{Metode Kualitatif}

Adalah pertanyaan yang bersifat wawancara melalui angket.

\subsection{Metode Kuantitatif}

Mencakup data dari survei nilai tatabahasa dan angket. Pada data kuantitatif yang akan digunakan sebagai bahan perbandingan adalah nilai UTS dan UAS dari mahasiswa tingkat satu (tahun pertama) selama dua semester dari tiga kelas pelajaran tatabahasa, yaitu 1. Kelas konvensionl atau sistem face to face murni, 2. MCL + off class, 3. MCL tanpa off-class. Pada kelas MCL OFC, aktivitas yang dilakukan mahasiswa pada waktu OFC terdiri dari tiga bagian. Bagian pertama adalah memberikan bahan bacaan dari website kepada para mahasiswa melalui discussion board. Bacaan yang ada sudah ada cara bacanya oleh penutur asli. Setelah membaca teks, mahasiswa menjawab pertanyaan. Tujuan aktivitas ini adalah untuk 
meningkatkan kemampuan membaca dengan nada dan lafal yang benar serta menambah kosa kata. Bagian kedua adalah dengan memberikan alamat website yang berisi percakapan sederhana dan menugaskan mahasiswa meringkas percakapan tersebut dengan kata-kata sendiri. Jawaban mahasiswa di-posting melalui forum discussion board. Pada pertemuan berikutnya, mahasiswa menceritakan isi percakapan tersebut dengan kata-kata sendiri. Keuntungan aktivitas ini adalah mahasiswa mampu mendengar percakapan dengan nada dan lafal yang tepat dari penutur asli. Hal itu diharapkan dapat meningkatkan kemampuan mendengar mahasiswa. Bagian ketiga adalah mahasiswa meringkas tata bahasa dari web-site yang diberikan dan kemudian mengerjakan latihan tata bahasa yang disediakan berupa menyusun kalimat yang diacak dan menyusun kalimat dari kosa kata yang diberikan.

\subsection{Tahapan Metode}

Tahapan Metode yang digunakan adalah SDLC (Sistem Development Life Cycle).

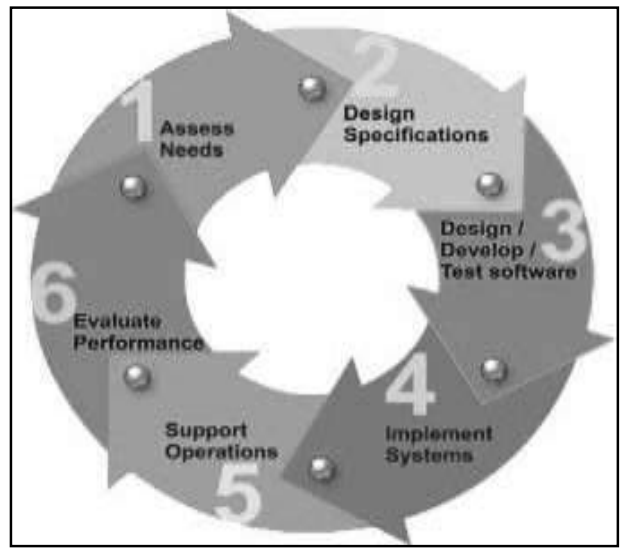

Gambar 1. Tahapan SDLC

Tahapan terapan

1) Action Research yaitu penerapan penelitian yang dilakukan dengan berfokus pada tindakan sosial yaitu mengamati langsung terhadap perkembangan dan penguasaan teknologi komputer yang digunakan oleh perguruan tinggi.

2) Experiment yaitu melakukan simulasi sesuai dengan hasil pengamatan yang akan diterapkan dalam sistem MCL. Dalam tahap ini tempat untuk melakukan experiment adalah tiga laboratorium pendukung yang ada di Universitas Mulia,
yaitu
laboratorium
basisdata, programming dan jaringan.

3) Case Study yaitu membantu menyelesaikan kasus-kasus spesifik yang pernah terjadi pada masyarakat dalam penggunaan layanan informasi.

4) Survey yaitu penelitian yang dilakukan dengan melakukan pengajuan pertanyaan tertulis atau yang dikenal dengan kuisioner ataupun dengan cara wawancara.

\subsection{Relasi tabel sistem MCL}

Berikut ini adalah relasi table pada multichannel learning yang dirancang, tabel tersebut akan diimplementasikan pada web. Relasi tersebut merupakan bagian dari MCL yaitu model e-learning yang akan diterapkan pada $e$-business management.

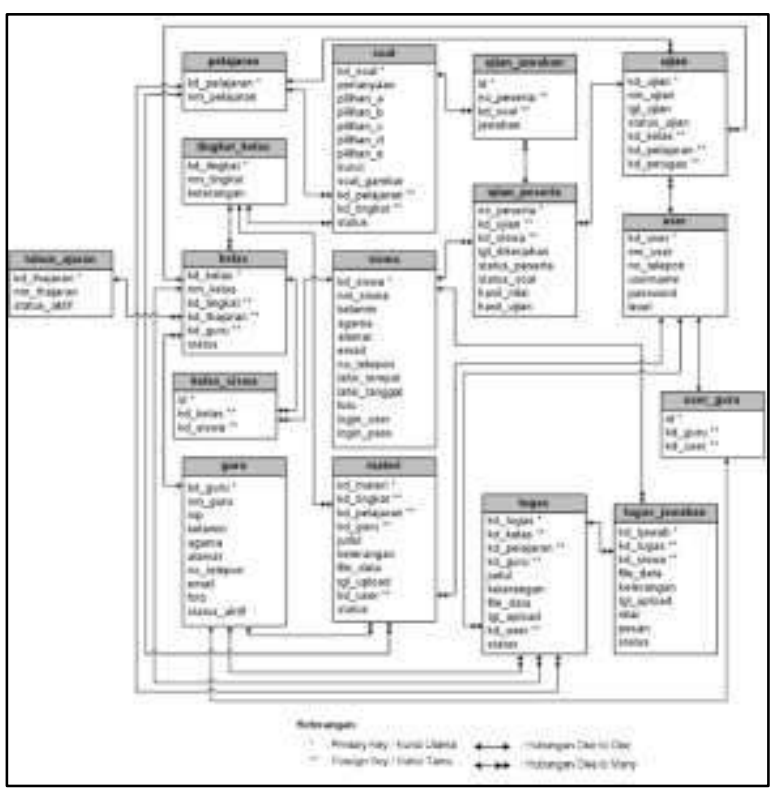

Gambar 2. Relasi Tabel pada MCL

\subsection{Lokasi Penelitian}

Lokasi Penelitian bertempat di Universitas Mulia di Kota Balikpapan, yaitu fokus pada laboratorium diantaranya:

1. Laboratorium Basisdata

2. Laboratorium Programming

3. Laboratorium Jaringan

\subsection{Rancangan Penelitian}

Dalam penelitian ini menggunakan model waterfall. 


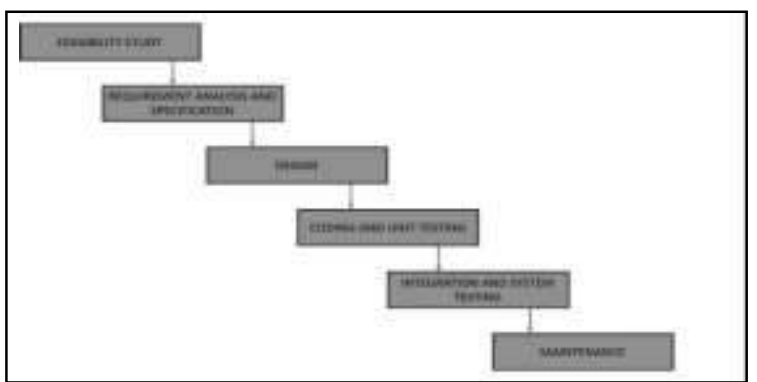

Gambar 3. Model Waterfall

Dalam pengembangannya metode waterfall memiliki beberapa tahapan yang runtut: requirement, design, implementation, verification dan maintenance. Pada penelitian MCL ini menggunakan model waterfall dimana tahap requirement atau spesifikasi kebutuhan sistem adalah analisa kebutuhan sistem yang dibuat dalam bentuk yang dapat dimengerti oleh user dalam hal ini masyarakat dan operator sistem atau pengembang. Dalam tahap ini user atau pengguna menjelaskan segala kendala dan tujuan serta mendefinisikan apa yang diinginkan dari sistem. Setelah dokumen spesifikasi disetujui maka dokumen tersebut menjadi kontrak kerja antara user dan perguruan tinggi. Tahap selanjutnya adalah desain, dalam tahap ini perguruan tinggi akan menghasilkan sebuah arsitektur sistem secara keseluruhan, dalam tahap ini menentukan alur perangkat lunak hingga pada tahap algoritma yang detil. Selanjutnya tahap implementasi, yaitu tahapan dimana keseluruhan desain diubah menjadi kode-kode program. Kode program yang dihasilkan masih berupa modul-modul yang selanjutnya akan di integrasikan menjadi sistem yang lengkap untuk meyakinkan bahwa persyaratan perangkat lunak telah dipenuhi. Tahap selanjutnya adalah verifikasi oleh user, user menguji apakah sistem tersebut telah sesuai dengan kontrak yang telah disetujui. Tahap akhir adalah pemeliharaan yang termasuk diantaranya instalasi dan proses perbaikan sistem.

\subsection{Teknik Pengumpulan Data}

Adapun tiga teknik pengumpulan data yang biasa digunakan adalah angket, observasi dan wawancara.

1) Angket/kuesioner, adalah teknik pengumpulan data yang dilakukan dengan cara memberikan seperangkat pertanyaan atau pernyataan kepada orang lain.

2) Observasi, merupakan salah satu teknik pengumpulan data yang tidak hanya mengukur sikap dari responden (wawancara dan angket) namun juga dapat digunakan untuk merekam berbagai fenomena yang terjadi (situasi dan kondisi).

3) Wawancara, teknik pengumpulan data yang dilakukan melalui tatap muka dan tanya jawab langsung antara pengumpul data maupun peneliti terhadap nara sumber atau sumber data.

\section{Hasil Penelitian}

\subsection{Sistem MCL}

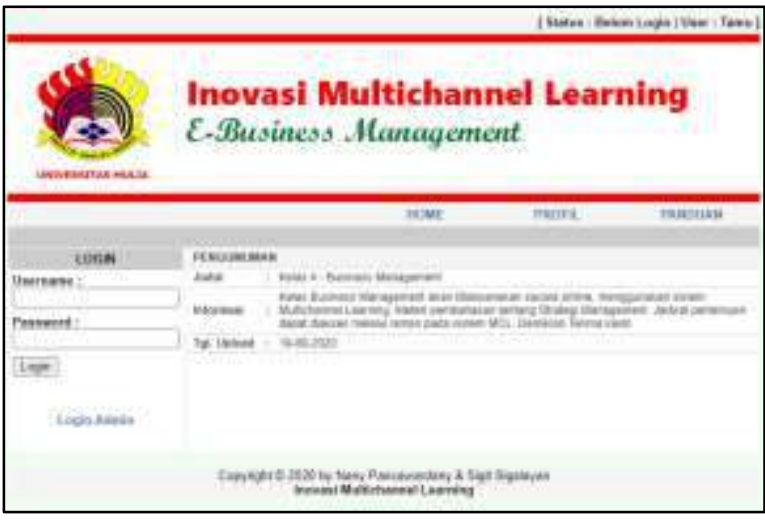

Gambar 4. Sistem Inovasi MCL

\subsection{Instruksi Kerja Sistem}

1) User

Data User adalah pihak yang boleh menggunakan program aplikasi, di dalam tabel user tersimpan banyak User (pengguna program) dengan level; Administrator, Petugas dan Dosen. Semua data Password (kata kunci) tersimpan dengan menggunakan enkripsi tipe MD5, sehingga jika dilihat berisi susunan karakter yang sulit dibaca.

Untuk level Admin, maka hak aksesnya dibuat Administrator, yaitu bisa mengakses semua halaman.

Untuk level Petugas, maka hak aksesnya boleh mengakses semua halaman, kecuali pada bagian halaman Data User tidak diperbolehkan.

Khusus untuk level akses Dosen, berarti data User tersebut dimiliki oleh data Dosen tertentu. Antara data User dan 
data Dosen, kepemilikan login dihubungkan dengan tabel relasi bernama user_Dosen. Di dalam tabel ini, antara User dan Dosen memiliki hubungan relasi One to One, artinya satu Dosen hanya memiliki satu User saja.

Penambahan data User dengan level Dosen secara otomatis dilakukan dari halaman Dosen, pada saat menambah Dosen baru, maka secara otomatis data User dengan Level Dosen akan ditambahkan, begitu juga saat menghapus data Dosen, maka data User milik Dosen terkait juga akan dihapus.

2) Materi

Data Materi adalah materi belajar yang dibuat oleh Dosen untuk Pelajaran pada Jurusan tertentu. Materi ini tidak dibuat hanya pada Kelas tertentu saja, melainkan dibuat untuk Pelajaran dalam satu Jurusan. Jadi, semua Peserta didik yang ingin mempelajari Materi dalam Pelajaran yang saat ini aktif dapat mengambil (Download). Data materi belajar disimpan dalam tabel materi, sedangkan file data disimpan dalam folder asset/materi.

Data Materi dapat di-Upload oleh semua User, baik Admin, Petugas maupun user sebagai Dosen.

Apabila materi belajarnya lebih dari 1 file dokumen (DPF/ Doc), maka dapat memaketnya dengan Win Rar atau Win Zip.

File Materi yang di-Upload tadi dapat di-Download (diunduh) ole Peserta didik dari halaman Login Peserta didik

3) Tugas Belajar

Data Tugas adalah tugas belajar yang diberikan oleh masing-masing Dosen yang mengajar mata Pelajaran tertentu dalam Kelas, data ini disimpan di dalam tabel tugas. Jadi, tugas belajar ini akan diberikan secara khusus untuk Kelas tertentu, bukan untuk semua Kelas.

Berikut beberapa tampilan Inovasi MCL menggunakan web

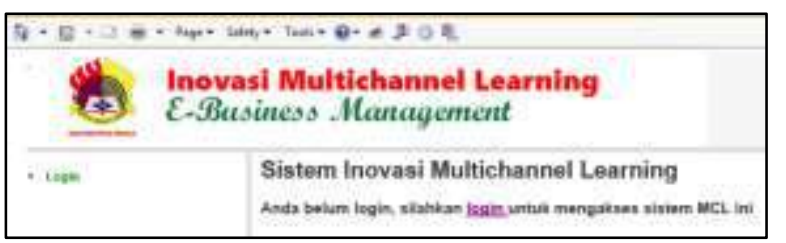

Gambar 5. Level Admin

Pada admin sistem MCL terdapat menu yang disiapkan khusus untuk dosen dan peserta didik. Berikut tampilan identitas dosen yang telah diinput dalam system.

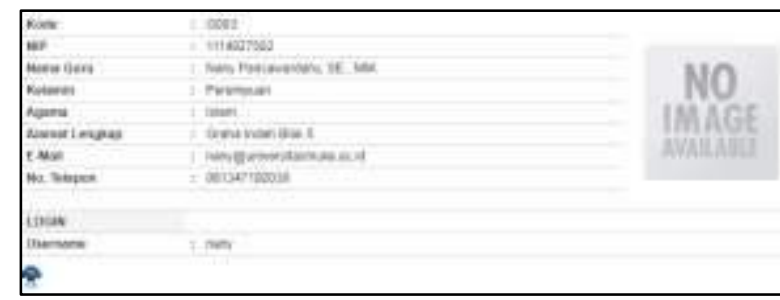

Gambar 5. Data dosen pengajar

Begitu pula pada admin juga masing-masing dosen dan peserta didik dapat mengupdate data sewaktu-waktu sesuai dengan data pada akademik.

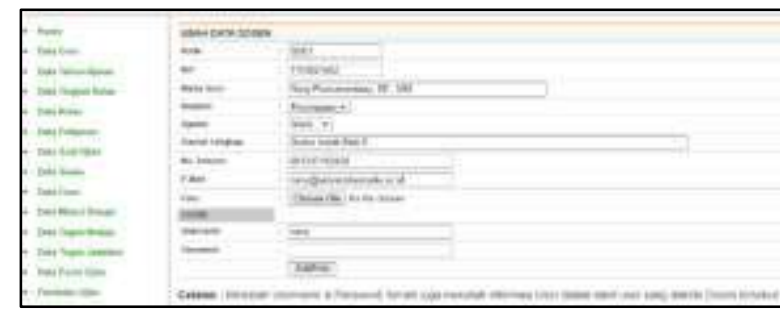

Gambar 6. Update Data

Berikut pemberikan soal dari dosen untuk dikerjakan oleh peserta didik melalui system MCL. Soal dapat berupa

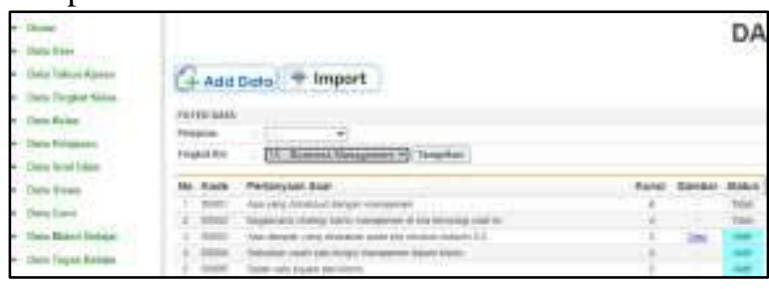

Gambar 7. Input Dan Import Data Soal

\section{Kesimpulan}

Multichannel learning pada matakuliah e-business management dapat membantu peserta didik dan dosen dalam perkuliahan, menerima dan menyampaikan materi dan tugas dapat dilakukan secara realtime, serta dapat memonitoring kemampuan peserta didik dalam menyelesaikan matakuliah 
tersebut. Sebagaimana merujuk pada gambar 8 berikut.

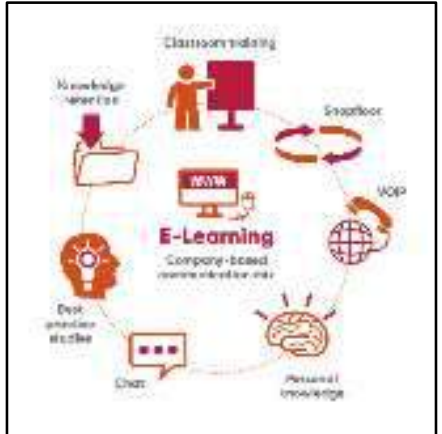

Gambar 8. E-learning/ Blended Learning

(source: https://www.progemma.com)

\section{Saran}

Multichannel yang dirancang dan dibangun menggunakan sistem web ini dapat dikembangkan lebih lanjut menggunakan aplikasi mobile sehingga dapat berjalan pada smartphone tanpa harus browsing seperti sebelumnya. Dan untuk meningkatkan kualitas keamanan pada sistem tersebut, dapat dikembangkan model hybrid.

\section{Daftar Pustaka}

[1] M. Harsasi, "The use of open educational resources in online learning: A study of students' perception," Turkish Online J. Distance Educ., 2015, doi: 10.17718/tojde.46469.

[2] G. Ifijeh, J. Iwu-James, and I. Osinulu, "From binding to digitization: Issues in newspaper preservation in Nigerian academic libraries," Ser. Rev., 2015, doi: 10.1080/00987913.2015.1103153.

[3] 2016 Komendangi, "learning adalah singkatan dari elektronic learning, dimana proses belajar mengajar yang menggunakan media elektronik secara khusus internet sebagai sistem pembelajarannya," J. Chem. Inf. Model., 2013, doi: 10.1017/CBO9781107415324.004.

[4] T. R. Whitworth, "Teen Childbearing and Depression: Do Pregnancy Attitudes Matter?," J. Marriage Fam., 2017, doi: 10.1111/jomf.12380.

[5] D. Kisanga and G. Ireson, "Barriers and strategies on adoption of e - learning in Tanzanian higher learning institutions: Lessons for adopters," Int. J. Educ. Dev.
Using Inf. Commun. Technol., 2015.

[6] B. Gibbons-Kunka, "Synchronous Office Hours in an Asynchronous Course," Int. J. Inf. Commun. Technol. Educ., 2017, doi: 10.4018/ijicte.2017100108.

[7] J. M. Case and D. Marshall, "Approaches to Learning," in The Routledge International Handbook of Higher Education, 2019.

[8] M. Yalman, "Preservice teachers' views about E-book and their levels of use of Ebooks," Turkish Online J. Educ. Technol., 2014.

[9] D. Desplaces, C. Blair, and T. Salvaggio, "Do E-learning Tools Make a Difference? Results from a Case Study.," Q. Rev. Distance Educ., 2015.

[10] P. D. Wedemeyer, "A discussion of auditor judgment as the critical component in audit quality- A practitioner's perspective," Int. J. Discl. Gov., 2010, doi: 10.1057/jdg.2010.19.

[11] S. M. Plis et al., "Deep learning for neuroimaging: A validation study," Front. Neurosci., $\quad 2014, \quad$ doi: 10.3389/fnins.2014.00229.

[12] D. B. Setyohadi, M. Aristian, B. L. Sinaga, and N. A. A. Hamid, "Social critical factors affecting intentions and behaviours to use E-learning: An empirical investigation using technology acceptance model," Asian J. Sci. Res., 2017, doi: 10.3923/ajsr.2017.271.280.

[13] R. Zain and A. T. R. D. Yuliana, "Pengaruh Kompensasi dan Kepuasan Kerja terhadap Kinerja Dosen di Fakultas Ilmu Tarbiyah dan Keguruan UIN Sunan Kalijaga Yogyakarta," Manag. J. Manaj. Pendidik. Islam, 2017, doi: 10.14421/manageria.2017.21-06. 